Ferranti, although smaller, is on the face of things more serious. Ferranti bought a US defence electronics company in 1988 and alleged last summer that it had been induced to pay $\$ 200$ million above the odds because supposed defence contracts with third parties were figments of creative imagination. Ferranti, which is technically an excellent enterprise, nearly went under and is now much emasculated by enforced disposals. In each case, nontechnical professionals, mostly accountants, appear to have failed to recognize a house of cards when asked to look at one. In both cases, strategically important technical enterprises seem to have been damaged by nontechnical negligence. Apart from those employed, the chief losers are the 'shareholders' who nowadays are present or would-be pensioners and insurance beneficiaries.

There is no great lesson to be drawn from these affairs - only a little irony. In science, some pride may derive from knowing that more exacting standards of prudence apply to research than to other professional activities, but should the difference be so great? Imprudence on this scale is not exclusively British - the $\$ 500,000$ million US taxpayers will have to spend in the next decade making up for imprudent arrangements of domestic mortgages would be enough to breathe new life into the Soviet Union, Eastern Europe or perhaps both.

\section{Extreme prejudice}

Europe and the United States have been too quick with scepticism of the latest offer of collaboration from Japan.

THE Japanese scheme for an international effort to develop intelligent manufacturing systems (IMS) has run into the troubles (see page 563) that plagued the Human Frontiers Science Programme (now rescued from scepticism, but with less to spend). First, there is incomprehension; people elsewhere say they do not understand what is proposed. Then there is suspicion; people elsewhere say that Japan must be be plotting yet another way of reinforcing its industrial supremacy. Finally, there is a reaction - heavyhanded determination by the United States and the European Communities that the project should not go ahead in the form proposed, or on terms substantially different from the collaborative projects with which they are themselves familiar. The result may be to turn an imaginative project into dust and ashes.

That people do not readily understand Japan is a forgivable commonplace, but in their own interests they should try harder. By occidental standards, the original version of IMS was vague: "let there be an international collaboration to develop new manufacturing technology". The original idea came from the University of Tokyo, with support (which meant publicity, not money) from the Ministry of International Trade and Industry (MITI). What can such a vague description mean? The headphones attached to cassette players now attached to many young people's heads may have sprung from some research director's demand "let us make a portable music system". (The word "Walkman" would have come later.) Envious Western manufacturers would profit from asking themselves some Japanese-style general questions.

The paranoia with which the Japanese proposal has been greeted is similarly misplaced. IMS was meant to be a club to which manufacturing companies would individually subscribe. There would be some MITI money to oil the wheels, perhaps even an international institute. But the US government has taken offence that US manufacturers have been approached directly, not through diplomatic channels, while the European Commission fears that companies from member states would be fleeced of their intellectual property with the first yen of MITI money that came their way. So IMS has been turned into a government-supervised project hardly different from European Eureka.

The plain truth is that the non-Japanese companies likely to be interested in the venture are well able to look after themselves, but stand to gain from collaboration of this kind of access to markets dominated by the Japanese. In its original form, IMS also offered ways in which technologists from elsewhere might learn at first hand how Japanese companies set about research and development, thus turning the US government's standard complaint that Japan is too secretive in this regard. To have responded with such suspicion to the proposal can only confirm Japanese industry in the belief that it has nothing to fear from its nominal competitors elsewhere.

\section{Pre-publicity}

Journals like this frown on pre-publicity for what they publish, but there must be exceptions.

THE development of a potential subunit vaccine for AIDS, reported on page 622 , is clearly important. But can it have been proper that Genentech should have made the gist of this discovery available to its shareholders two weeks ago, in advance of a shareholders' meeting to decide whether the proposed merger with Roche should go ahead?

The circumstances are these. The authors of the research enquired three weeks ago whether they would be able to use the information as they did, saying that they were aware of the policy of this journal (and others) that prior notice of publication should not be formally provided and offering to withdraw the research report if shareholders could not otherwise be informed. This journal's restrictive policy on prior publicity derives from a wish not to be pre-empted by less substantial sources of information - in Nature one day but in the New York Times the day before, for example. But the policy is not rigid, and may be broken when there is information of urgent public importance to report. Moreover, the policy is not intended to (and should not) inhibit discussion at regular scientific meetings. Do not shareholders also have rights? 